\title{
PENGEMBANGAN MEDIA DVD INTERAKTIF DAN VIDEO TENTANG MENU SEHAT SEIMBANG BALITA UNTUK KADER POSYANDU
}

\author{
Mutiara Dahlia, Rusilanti, Sachriani, Nur Riska T. \\ Tata Boga, Fakultas Teknik, Universitas Negeri Jakarta \\ Email: mutiaradahlia@yahoo.com
}

\begin{abstract}
This study analyses the effectiveness of instructional media using Digital Video Disc (DVD) and videos in nutrition education concerning the development of toddlers' food preferences of balanced meals based on community empowerment. The media was expected to be used by the cadre of Posyandu (Maternal and Child Health Centre) and housewives in Rawamangun village. This study used the quasi experiment method. The data analysis showed the score of $F$ was 15.89 that was higher than the F table with the score of 4.11 in the significance level of 0.05. It indicates the learning outcomes of the instructional media using DVD and videos was higher than using handouts. The result of this study was a nutrition education model concerning the development of toddlers' food preferences of balanced meals in the form of DVD and videos that can be effectively applied. The media is able to improve the learning outcomes of nutrition education including the knowledge and the skills. Thus it indirectly supports the government program in community empowerment.
\end{abstract}

Keywords: healthy balanced meal, interactive, media development, posyandu cadre, toddlers

\begin{abstract}
ABSTRAK
Penelitian ini dilakukan bertujuan untuk menganalisis efektivitas penggunaan media dalam bentuk DVD interaktif dan video dalam perancangan model pendidikan tentang pembentukan kesukaan balita terhadap makanan bergizi seimbang pada ibu berbasis pemberdayaan masyarakat yang dapat digunakan oleh kader posyandu dan ibu rumah tangga kelurahan Rawamangun. Metode quasi experiment. Hasil analisis varians dua jalur antar kolom diperoleh harga $\mathrm{F}_{\text {hitung }}=15,89$ lebih besar dibandingkan $\mathrm{F}_{\text {tabel }}=4,11$ pada taraf signifikansi $\alpha=$ 0,05. Nilai ini menunjukkan bahwa hasil belajar kader posyandu dengan media dalam bentuk DVD dan video lebih baik dibandingkan dengan media handout. Hasil penelitian dapat membentuk suatu model pendidikan gizi yaitu media dalam bentuk DVD interaktif dan video tentang pembentukan kesukaan anak terhadap makanan bergizi seimbang yang diterapkan. Media dan metode tersebut dapat meningkatkan hasil belajar berupa pengetahuan dan keterampilan dalam penyuluhan gizi pada ibu, kader posyandu dan masyarakat sehingga secara tidak langsung dapat membantu program pemerintah dalam pemberdayaan masyarakat. The developed media improves the achievement of nutritional education of mothers, society and indirectly helped the government program in community empowerment.
\end{abstract}

Kata kunci: balita, interaktif, kader posyandu, menu sehat seimbang, pengembangan media

\section{PENDAHULUAN}

Gizi merupakan salah satu faktor penting untuk menentukan kualitas sumber daya manusia (Almatsier, 2002). Anak merupakan salah satu kelompok rawan gizi, pada usia ini pertumbuhan otak masih berlangsung cepat (Istiany Ari dan Rusilanti, 2013). Kurangnya pengetahuan gizi dan kesehatan orangtua, khususnya ibu merupakan salah satu penyebab kekurangan gizi pada anak (As'ad, Suryani, 2002). Berdasarkan data tahun 2006 di
Indonesia, jumlah anak yang mengalami gizi buruk mencapai 4,8 juta anak. Pada tahun 2007 ada penurunan, yaitu jumlah anak yang mengalami gizi buruk mencapai 4,1 juta anak Pada tahun 2008 juga mengalami penurunan dari tahun sebelumnya, yaitu jumlah anak yang mengalami gizi buruk mencapai 4 juta anak (Departemen Kesehatan, 2010).

Anak sangat tergantung dengan pola asuh orang tua, sehingga pengetahuan ibu berperan dalam status gizi anak (Moehji, 2003). Pola asuh terhadap anak berpengaruh terhadap 
timbulnya masalah gizi (PERSAGI, 2003). Perhatian cukup dan pola asuh yang tepat akan memberi pengaruh yang besar dalam memperbaiki status gizi (Depkes RI, 2002). Pemberdayaan sebagai proses mengembangkan, memandirikan, menswadayakan, memperkuat posisi tawar menawar masyarakat lapisan bawah terhadap kekuatan-kekuatan penekan di segala bidang dan sektor kehidupan (Sutoro, 2002). Permendagri RI Nomor 7 Tahun 2007 tentang kader pemberdayaan masyarakat, dinyatakan bahwa pemberdayaan masyarakat adalah suatu strategi yang digunakan dalam pembangunan masyarakat sebagai upaya untuk mewujudkan kemampuan dan kemandirian dalam kehidupan bermasyarakat, berbangsa dan bernegara (Pasal 1, ayat 8 ).

Penelitian tahap pertama menghasilkan media interaktif dalam bentuk DVD yang berisi materi tentang gizi terkait dengan kebutuhan gizi balita, pemilihan bahan makanan yang bergizi dan cara pengolahan makanan yang sehat seimbang dan disukai oleh anak balita. Hasil validasi yang diperoleh adalah sebagai berikut: Penilaian uji ahli materi (subject matter expert) untuk media interaktif dalam bentuk DVD dengan poin nilai 32. Nilai rata-rata yaitu 4,5 berada pada kriteria sangat baik. Penilaian untuk media interaktif dalam program Video dengan poin nilai 30 . Nilai rata-rata yaitu 4,28 berada pada kriteria sangat baik. Uji ahli media (media expert) pada media adalah dicapai adalah baik, yaitu dengan poin nilai 107. Hasil uji materi untuk media video berada pada kriteria baik, yaitu dengan poin nilai 110 . Nilai rata-rata keseluruhan yang didapat yaitu 3,67. Uji keefektifan model pendidikan mengetahui sejauh mana kegunaan media ini dilakukan. Uji keefektifan media ini dengan dua cara yaitu: Pre-test dengan menggunakan SPPS melalui uji wilcoxon dihasilkan mean $=13.70$ dengan $\min =$ 8 dan $\max =16$. Adapun Post-test juga menggunakan SPPS dengan uji wilcoxon dihasilkan mean $=13.95$ dengan $\min =10$. dan $\max =16$. Dengan demikian perbandingan rata.rata nilai pre-test dan post-test responden setelah diberikan media pembelajaran berupa
DVD dan Video menjawab soal, mengalami kenaikan sebesar 0,25 poin. Melalui tabel hasil uji peringkat bertanda Wilcoxon tersebut diperoleh tingkat signifikansi $(\alpha)$ yakni sebesar 0.005. Diketahui bahwa $0.0075<0.05$, ini menunjukkan bahwa tingkat signifikansi yang diperoleh $\mathrm{H} 1$ akan diterima. Artinya, dari hasil uji Wilcoxon ini dapat diketahui bahwa hasil post-test responden untuk kelas pengembangan media interaktif (DVD dan video) lebih besar daripada hasil pre-test mereka.

Sebagai tindak lanjut dari hasil penelitian tahap pertama maka pada tahap kedua akan dilakukan uji efektivitas penggunaan interaktif dalam bentuk DVD dan Video pada posyandu dengan membagi menjadi dua kelompok yaitu kelompok yang diberikan perlakuan dengan menggunakan interaktif dalam bentuk DVD dan video. Adapun kelompok kontrol yang tidak menggunakan media tersebut, namun hanya menggunakan handout. Hal ini untuk melihat bagaimana efektivitas media yang digunakan dalam pembelajaran membentuk preferensi anak terhadap makanan seimbang memberikan hasil yang baik. Selanjutnya ditelusuri apakah ibu yang memiliki balita dan telah mendapatkan penyuluhan dari kader posyandu dengan menggunakan media tersebut menerapkan pengetahuannya dalam menyiapkan makanan bagi anak balita sesuai dengan apa yang telah disampaikan dalam penyuluhan, serta mencari informasi apakah anak balita menyukai makanan yang disiapkan ibu tersebut.

\section{METODE}

Penelitian ini dilaksanakan di posyandu yang berada di Kelurahan Rawamangun, Jakarta Timur. Pengambilan data dilaksanakan pada dua Posyandu. Posyandu tersebut memiliki kader sebanyak sekitar 20 orang serta ibu yang memiliki balita dengan jumlah 20 orang. Penelitian ini bertujuan untuk menganalisis efektivitas penggunaan media interaktif dalam bentuk DVD dan video dalam perancangan model pendidikan tentang pembentukan kesukaan anak terhadap makanan bergizi 
seimbang pada ibu berbasis pemberdayaan masyarakat yang dapat digunakan oleh kader posyandu dan ibu rumah tangga Kelurahan Rawamangun.

Penelitian ini menggunakan metode quasi experiment dengan menggunakan dua kelompok yaitu kelompok kontrol dan kelompok eksperimen (Sugiyono, 2010). Prosedur penelitian terdiri dari: (1) kelompok dibagi dua yaitu kelompok kontrol dan kelompok perlakuan. (2) Sebelum dilakukan penyuluhan pada kedua kelompok dilakukan pre-test. (3) Pada kelompok kontrol dilakukan penyuluhan dengan menggunakan media handout. (4) Pada kelompok perlakuan dilakukan penyuluhan dengan menggunakan media interaktif dalam bentuk DVD dan video dengan didahului dengan pembukaan dan penjelasan singkat tentang tujuan penyuluhan. (5) Setelah selesai penyuluhan pada kedua kelompok dilakukan post-test. (6) Perbedaan hasil yang diperoleh diuji dengan menggunakan uji Wilcoxon

Seluruh data yang dikumpulkan dianalisis untuk diketahui bagaimana penilaian responden terhadap program yang baru saja diuji coba. Tiap aspek yang dinilai minimal harus memperoleh skor 3 (cukup), apabila kurang dari cukup maka pada aspek tersebut harus diperbaiki. Data dari hasil pengukuran hasil belajar berupa pengetahuan dan keterampilan harus memenuhi persyaratan analisis data melalui uji normalitas dan uji homogenitas. Pengujian normalitas data dilakukan dengan menggunakan Liliefors. Data dianalisis yang terdiri dari analisis deskriptif dan analisis inferensial.

Data yang telah diuji bila berasal dari populasi yang berdistribusi normal dan keempat kelompok data (sampel) yang tidak saling berhubungan mempunyai variansi populasi yang homogen maka telah memenuhi syarat untuk dianalisis dengan menggunakan teknis analisis data melalui uji Wilcoxon. Apabila hasil analisis menunjukan adanya perbedaan dari kelompok perlakuan, perbedaan dari variabel bebas terhadap variabel terikat dan terdapat interaksi antara variabel bebas dengan variabel terikat, maka analisis akan dilanjutkan dengan uji Tukey guna menguji hipotesis lebih lanjut (Arikunto Suharsimi, 2007).

\section{HASIL DAN PEMBAHASAN}

Tabel 1 menunjukkan bahwa delapan kelompok yang diuji dengan uji Liliefors lebih kecil dari $\mathrm{L}_{\mathrm{t}}\left(\mathrm{L}_{\mathrm{o}}<\mathrm{L}_{\mathrm{t}}\right)$. Dengan demikian dapat disimpulkan bahwa semua kelompok data dalam penelitian ini berasal dari populasi yang berdistribusi normal. Hasil perhitungan dideskripsikan pada Tabel 1 berikut.

Tabel 1. Hasil Uji Normalitas Distribusi Populasi Data Penelitian

\begin{tabular}{llllll}
\hline No Kelompok & $\mathrm{n}$ & $\mathrm{L}_{\mathrm{o}}$ & $\mathrm{L}_{\mathrm{t}}$ & Kesimpulan \\
\hline 1 & $\mathrm{~A}_{1}$ & 20 & 0,112 & 0,190 & Normal \\
2 & $\mathrm{~A}_{2}$ & 20 & 0,078 & 0,190 & Normal \\
3 & $\mathrm{~B}_{1}$ & 20 & 0,12 & 0,190 & Normal \\
4 & $\mathrm{~B}_{2}$ & 20 & 0,14 & 0,190 & Normal \\
5 & $\mathrm{~A}_{1} \mathrm{~B}_{1}$ & 10 & 0,154 & 0,258 & Normal \\
6 & $\mathrm{~A}_{1} \mathrm{~B}_{2}$ & 10 & 0,221 & 0,258 & Normal \\
7 & $\mathrm{~A}_{2} \mathrm{~B}_{1}$ & 10 & 0,14 & 0,258 & Normal \\
8 & $\mathrm{~A}_{2} \mathrm{~B}_{2}$ & 10 & 0,17 & 0,258 & Normal \\
\hline
\end{tabular}

Setelah uji persyaratan terpenuhi maka analisis Wilcoxon dapat dilakukan untuk menguji hipotesis penelitian. Jika terdapat interaksi maka dilakukan uji lanjut dengan menggunakan uji Tuckey. Berdasarkan hasil perhitungan di atas dapat dijelaskan bahwa terdapat perbedaan hasil belajar antara kader posyandu yang menggunakan media dalam bentuk DVD dan video dengan kader posyandu yang menggunakan media handout. Rata-rata hasil belajar kader posyandu kelompok $\mathrm{A}_{1}=79$ secara signifikan lebih besar dari rata rata kelompok $\mathrm{A}_{2}=70$. Berdasarkan tabel perhitungan $\mathrm{F}_{\text {hitung }}>\mathrm{F}_{\text {tabel }}(0,05) ; 12,47>4,11$, maka menolak $\mathrm{H}_{0}$ sehingga terdapat perbedaan yang sangat signifikan pada kedua media pembelajaran yakni $\mathrm{A}_{1}$ (media dalam bentuk DVD dan video) dan $\mathrm{A}_{2}$ (media handout)

Untuk menguji persyaratan normalitas data menggunakan uji Liliefors pada hasil pengetahuan pada ibu yang menggunakan 
media handout tentang makanan kesukaan anak terhadap makanan bergizi seimbang di Posyandu Cempaka, kelurahan Rawamangun. Sedangkan pengetahuan pada ibu menggunakan media flash tentang makanan kesukaan anak terhadap makanan bergizi seimbang di Posyandu Soka Kelurahan Rawamangun. Hasil pengujian seperti Tabel 2.

Tabel 2. Rekapitulasi Uji Normalitas Para Ibu Kelompok Handout

\begin{tabular}{lllr}
\hline Ratarata & 75 & Lh $=$ & 0,836 \\
\hline STDEV & 4,792235 & L tab & 0,162 \\
Varians & 22,97 & Lh $>$ Ltab & \\
& & Tidak & terdistribusi \\
& & normal & \\
\hline
\end{tabular}

Berdasarkan data L hitung diperoleh 0,836. Jika dikonversikan dengan $\mathrm{L}$ tabel sebesar 0,162 . Maka, L hitung $>\mathrm{L}$ tab, artinya $\mathrm{H}_{0}$ diterima sehingga nilai pengetahuan pada ibu yang menggunakan handout tidak berdistribusi normal. Rekapitulasi uji normalitas para ibu kelompok DVD dan video dapat dilihat pada Tabel 3.

Tabel 3. Rekapitulasi Uji Normalitas Para Ibu Kelompok DVD dan video

\begin{tabular}{llll}
\hline Ratarata & 80 & skor Maks $=$ & \\
& & & 0,528 \\
\hline STDEV & 4,368645 & L tab $=$ & \\
& & & 0,162 \\
Varians & 19,0851 & Lh $>$ Ltab & \\
& & $\begin{array}{l}\text { Tidak } \\
\text { terdistribusi } \\
\end{array}$ & \\
& & normal & \\
\hline
\end{tabular}

Berdasarkan data di atas $\mathrm{L}$ hitung diperoleh 0,528. Jika dikonversikan dengan $\mathrm{L}$ tabel sebesar 0,162. Maka, L hitung $>\mathrm{L}$ tab, artinya $\mathrm{H}_{0}$ diterima sehingga nilai pengetahuan pada ibu yang menggunakan DVD berbasis flash dan video tidak berdistribusi normal. Selanjutnya untuk menguji hipotesis apakah terdapat perbedaan antara pengetahuan pada ibu yang menggunakan handout sebagai kelompok kontrol dan pengetahuan para ibu yang menggunakan media DVD berbasis flash dan video sebagai kelompok eksperimen, diuji menggunakan uji perbandingan. Karena hasil ujian persyaratan analasis kedua kelompok tidak bersdistribusi normal, maka menggunakan uji non parametrik yakni uji Wilcoxon.

Diketahui bahwa banyaknya skor pengetahuan tentang kesukaan anak dengan media DVD berbasis flash dan video yang lebih besar dari skor menggunakan handout, ada 21 ibu dan ada 3 orang yang skor menggunakan handout lebih besar dari skor dengan media DVD berbasis flash dan video. Hal ini menunjukkan bahwa penggunaan media flash lebih dapat meningkatkan hasil belajar atau tingkat pengetahuan para ibu bila dibandingkan dengan media handout. Hasil test statistics nilai Z sebesar 3.609. Jika level signifikansi 0.05 dan menggunakan uji dua sisi. Nilai Z kritis antara 1.645 dan 1.645, yang berarti berada di daerah penerimaan H1. Begitu juga dengan nilai signifikansi pvalue sebesar $0.00013(<0.05)$ maka tolak hipotesis nol (Ho). Jadi kesimpulannya terdapat perbedaan skor pengetahuan pada ibu tentang makanan bergizi seimbang yang signifikan terhadap perlakuan media flash dan kontrol dengan handout. Berdasarkan deskripsi dari hasil penelitian yang telah dianalisis di atas menunjukkan bahwa media flash dalam bentuk DVD dan video tentang makanan bergizi seimbang untuk balita memiliki hasil yang lebih baik dibandingkan dengan media handout, sehingga media interaktif dalam bentuk DVD dan video secara efektif dapat meningkatkan hasil belajar kader posyandu lebih baik daripada menggunakan media handout.

\section{SIMPULAN}

Berdasarkan hasil analisis data yang diperoleh, maka dapat disimpulkan sebagai berikut secara umum media dalam bentuk DVD dan video tentang makanan bergizi seimbang untuk balita lebih baik dibandingkan dengan media handout dalam meningkatkan hasil belajar kader posyandu. Artinya, hasil belajar kader posyandu dalam penyuluhan gizi tentang 
makanan bergizi seimbang untuk balita lebih efektif meningkat dengan menggunakan media dalam bentuk DVD dan Video. Diharapkan setelah penelitian ini para ibu rumah tangga dapat mempunyai pengetahuan dalam memilih variasi menu untuk anak balita. Sehingga penyuluhan tentang pembentukan kesukaan anak terhadap makanan bergizi seimbang pada ibu berbasis pemberdayaan masyarakat diterima masyarakat. Disarankan agar kader posyandu menggunakan media pembelajaran dan metode pembelajaran yang sesuai dan tepat dalam penyuluhan gizi sehingga meningkatkan pengetahuan dan keterampilan ibu dalam membentuk kesukaan makanan bergizi seimbang pada anak balita.

\section{DAFTAR RUJUKAN}

Almatsier, Sunita. 2002. Prinsip Dasar Ilmu Gizi. Jakarta: Gramedia

Arikunto Suharsimi, 2007. Manajemen Penelitian. Jakarta: Rieneka Cipta

As'ad, Suryani. 2002. Gizi Kesehatan Ibu dan Anak. Depdiknas. Jakarta

Departemen Kesehatan. 2002. Pemantauan Kesehatan Balita. Jakarta: Departemen Kesehatan RI
Departemen Kesehatan RI. 2010. Capaian Pembangunan Kesehatan Tahun 2011. Jakarta: Departemen Kesehatan RI

Istiany Ari dan Rusilanti. 2013. Gizi Terapan. Jakarta: Rosda

Moehji, S. 2003. Ilmu Gizi: Penanggulangan Gizi Buruk. Jakarta: Papas Sinar Sinanti.

Peraturan Menteri Dalam Negeri RI Nomor 7 Tahun 2007 tentang Kader Pemberdayaan Masyarakat. Bandung: Fokus Media

PERSAGI, 2003. Penuntun Diit Anak. Jakarta: Gramedia

Sugiono. 2010. Statistika untuk Penelitian. Bandung: Alfabet

Sutoro Eko. 2002. Pemberdayaan Masyarakat Desa. Materi Diklat Pemberdayaan Masyarakat Desa, yang diselenggarakan Badan Diklat Provinsi Kaltim Samarinda. Desember 2002 